\title{
Deference to the administration in judicial review - the European Union
}

Citation for published version (APA):

Eliantonio, M. (2019). Deference to the administration in judicial review - the European Union. In G. Zhu (Ed.), Deference to the administration in judicial review (pp. 165-179). Springer International Publishing. lus Comparatum - Global Studies in Comparative Law Vol. 39 https://dol.org/10.1007/978-3-030-315399_8

Document status and date:

Published: 01/01/2019

DOI:

10.1007/978-3-030-31539-9_8

Document Version:

Publisher's PDF, also known as Version of record

\section{Document license:}

Taverne

\section{Please check the document version of this publication:}

- A submitted manuscript is the version of the article upon submission and before peer-review. There can be important differences between the submitted version and the official published version of record.

People interested in the research are advised to contact the author for the final version of the publication, or visit the DOI to the publisher's website.

- The final author version and the galley proof are versions of the publication after peer review.

- The final published version features the final layout of the paper including the volume, issue and page numbers.

Link to publication

\footnotetext{
General rights rights.

- You may freely distribute the URL identifying the publication in the public portal. please follow below link for the End User Agreement:

www.umlib.nl/taverne-license

Take down policy

If you believe that this document breaches copyright please contact us at:

repository@maastrichtuniversity.nl

providing details and we will investigate your claim.
}

Copyright and moral rights for the publications made accessible in the public portal are retained by the authors and/or other copyright owners and it is a condition of accessing publications that users recognise and abide by the legal requirements associated with these

- Users may download and print one copy of any publication from the public portal for the purpose of private study or research.

- You may not further distribute the material or use it for any profit-making activity or commercial gain

If the publication is distributed under the terms of Article $25 \mathrm{fa}$ of the Dutch Copyright Act, indicated by the "Taverne" license above, 


\title{
Deference to the Administration in Judicial Review: The European Union
}

\author{
Mariolina Eliantonio
}

\begin{abstract}
The present contribution explores the approach of the Court of Justice of European Union towards the review of discretionary decisions adopted by the European Union (EU) administration. The analysis shows that the review of the European courts on the discretionary choices of the EU administration revolves around the concept of 'manifest error'. This term has acquired a different meaning throughout time, evolving from a very light review towards a deeper review, entailing an examination of whether the factual basis of a decision justifies the outcome of the decision itself. Furthermore, whenever the EU authorities are vested with the discretionary powers to weigh conflicting interests, the control of the European courts is exercised both through the tool of 'manifest error' and through the proportionality review. This review is relatively limited and will lead to a finding of unlawfulness only in cases of serious flaws.
\end{abstract}

\section{Introduction}

\subsection{The Judicial Architecture of the European Union}

In the European Union (EU) legal system, the judicial powers are exercised by a body referred to as 'Court of Justice of the European Union' (hereinafter: CJEU). This institution consists at present of two courts-the Court of Justice and the General Court. As a consequence of the reform of the General Court, which took effect as of September 2016, the Civil Service Tribunal has stopped operating and has been absorbed into the General Court. ${ }^{1}$ In the future, new specialised courts may

\footnotetext{
${ }^{1}$ Regulation EU 2015/2422 of the European Parliament and of the Council amending Protocol No 3 on the Statute of the Court of Justice of the European Union (Euratom) [2015] OJ L341/14.
}

M. Eliantonio ( $\bowtie)$

Maastricht University, Maastricht, The Netherlands

e-mail: m.eliantonio@maastrichtuniversity.nl 
be created in accordance with the procedure set up in Article 257 of the Treaty on the Functioning of the European Union (hereinafter: TFEU), in order to exercise judicial competence in certain specific areas.

The most important cases in which the General Court has jurisdiction concern actions for annulment of acts of the EU institutions under Article 263 TFEU and actions for failure to act on the side of the EU institutions under Article 265 TFEU brought by natural or legal persons (for example, a case brought by a company against a Commission decision imposing a fine on that company); actions seeking compensation for damage caused by the institutions or the bodies, offices or agencies of the European Union or their staff under Articles 268 and 270 TFEU; and actions based on contracts made by the European Union which expressly give jurisdiction to the General Court under Article 272 TFEU. The General Court may, therefore, be considered as the "administrative court" of the European Union, because it has jurisdiction to review acts of the European executive, namely the European Commission and the other institutions, bodies, agencies and offices of the European Union when they implement EU legislation.

The decisions of the General Court may, within 2 months, be subject to an appeal before the Court of Justice, limited to points of law. According to Article 256(3), the General Court has the jurisdiction to give preliminary rulings (Article 267 TFEU) in the areas laid down by the Statute. However, since no provisions have been introduced into the Statute in that regard, the Court of Justice currently has the sole jurisdiction to give preliminary rulings (i.e. rulings concerning the interpretation or validity of EU law sent by national courts). Apart from appeal functions against rulings of the General Court, the Court of Justice has jurisdiction in first and last instance in infringement proceedings under Articles 258-260 TFEU (i.e. actions brought by the Commission against a Member State for failure to fulfil its obligations and under EU law), and in proceedings against the EU institutions for annulment and for failure to act when they are brought by a Member State or an EU institution. ${ }^{2}$

In a similar manner to the French legal system, the judges of the Court of Justice are assisted by 11 Advocates General (hereinafter: AG) who are responsible for presenting a legal opinion on the cases assigned to them. In the EU legal order, the Advocate General is not part of the chamber determining the case, but participates in the oral proceedings and may question the parties. The Advocate General then delivers his or her opinion in public on the legal questions of the case, based on a thorough analysis akin to an academic discussion, and suggests how the court should decide. The opinion is always published separately and in full. In the General Court, there are no Advocates General, but the judges themselves may be called upon to perform the task of Advocate General.

\footnotetext{
${ }^{2}$ Please note that infringement proceedings and preliminary rulings will not be further dealt with in this contribution, as they do not have the nature of 'judicial review of administrative action'.
} 


\subsection{The Grounds of Review of Administrative Action}

In the European system, a fixed set of grounds for judicial review exists. In Article 263 TFEU, which stipulates the requirements for an action for annulment, specific reasons are listed. The claim can only be based 'on grounds of lack of competence, infringement of an essential procedural requirement, infringement of the Treaties or of any rule of law relating to their application, or misuse of powers'. Thus, complaints based on procedural grounds as well as claims based on the infringement of substantial law are covered. An action for failure to act, according to Article 265 TFEU, may be brought when the failure to act is allegedly 'in infringement of the Treaties'. The grounds for review were originally taken over from the French legal order, but they have developed autonomously and have currently an own distinct shape. These grounds only cover a review of legality of the EU action or inaction, which means that the European courts are precluded from assessing the merits of the actions or decisions reviewed. ${ }^{3}$ Judicial review of discretionary choices of the administration is carried through one specific ground of review, namely 'infringement of the Treaties or of any rule of law relating to their application'.

\subsection{The Concept of 'Discretion' in the EU Legal System}

In the EU legal system, there is no clear conceptual distinction between 'discretionary choices' and 'technical choices' (or, as some legal systems call it, 'technical discretion') of the EU administrative authorities. While it has been argued that the differentiation in references to concepts such as 'margin of appraisal', 'power of appraisal', 'discretion' or 'margin of discretion' might seem to indicate that the European courts try to differentiate such concepts, ${ }^{4}$ the doctrine is consistent in holding that no clear distinction between types of discretionary choices-akin to that made at national level—can be identified in the case law of the European courts. ${ }^{5}$ As is well known, this distinction is not necessarily an easy one to make. ${ }^{6}$

Discretion stricto sensu is taken in this contribution to mean the process through which the EU administration assesses and weighs competing public interests. 'Technical discretion' refers to the assessment, within the framework of set legislative criteria, of the aspects of the decision-making process that require expert knowledge (and which may ultimately leave no actual discretion stricto sensu to the authority). To the extent that this acquired technical knowledge still leaves room for choice, the authorities are then authorized to choose an alternative by exercising their 'technical

\footnotetext{
${ }^{3}$ Baran (2017), p. 295.

${ }^{4}$ Prek and Lefèvre (2019), p. 344.

${ }^{5}$ See e.g. Fritzsche (2010), p. 364; Schwarze (2006), p. 297; Widdershoven (2019), p. 53.

${ }^{6}$ See further on this point, Mendes (2016), pp. 419-452.
} 
discretion'. 7 This 'technical discretion' is exercised at EU level both at the moment of determination of a complex factual background and that of establishment of complex facts and their assessment in light of the relevant law. ${ }^{8}$

\section{Intensity of Review of 'Technical Discretion' in the EU Legal System: The Evolving Threshold of 'Manifest Error'}

The question of the appropriate standard of review in administrative decisionmaking of technical nature has come to the attention of the European courts most often in competition cases where the European courts, for example, scrutinize the decisions of the European Commission whereby the latter finds a violation of Article 101 (on anti-competitive agreements) or Article 102 (on abuse of dominant position) TFEU, or declares a concentration compatible or incompatible with the common market, and is thus faced with decisions that are the products of so-called 'complex economic assessments'. Another area where discretionary choices are often at stake is the Common Agricultural Policy, when for example the Commission is authorized to take stabilization measures if a certain market imbalance is likely to materialize. Although less often, the European courts have also scrutinized decisions requiring technical assessments in the field of protection of the environment and human health. ${ }^{10}$

\subsection{The Early Case Law and the 'Light-Touch' Approach}

Originally, when a EU body was vested with a wide margin of technical discretion, the perspective of the EU courts was that of clear deference to the discretionary choices of the administrative authorities. According to the early case law of the Court of Justice, judicial review should be limited to verifying 'whether the rules on

\footnotetext{
${ }^{7}$ Advocate General Leger calls this form of appraisal 'discretion of "technical" nature', see Opinion in C-40/03 P, Rica Foods (Free Zone) NV v Commission ECLI:EU:C:2005:93, para. 46; Schimmel and Widdershoven prefer the term 'margin of appreciation': Schimmel and Widdershoven (2009), p. 65. Paul Craig refers to this concept as 'jurisdictional discretion': Craig (2012), p. 404.

${ }^{8}$ Fritzsche (2010), p. 364.

${ }^{9}$ See e.g. Case 78/74, Deuka, Deutsche Kraftfutter GmbH, B. J. Stolp v Einfuhr- und Vorratsstelle für Getreide und Futtermittel, ECLI:EU:C:1975:44; Case 98/78, A. Racke v Hauptzollamt Mainz, ECLI:EU:C:1979:14.

${ }^{10}$ See e.g. Case C-77/09, Gowan Comércio Internacional e Serviços Lda v Ministero della Salute ECLI:EU:C:2010:803 concerning the question of whether a substance meets the safety requirements of Council Directive 91/414/EEC concerning the placing of plant protection products on the market.
} 
procedure and on the statement of reasons have been complied with, whether the facts have been accurately stated, and whether there has been any manifest error of assessment or misuse of powers'. ${ }^{11}$ In this early case law, the court's review of the discretionary choices of the EU administration is carried out without much argumentation and attention for the factual support of the conclusions reached by it. ${ }^{12}$ During this early period, 'review of the sufficiency of the evidence supporting an administrative measure is virtually non-existent' ${ }^{13}$

The rationale of this 'light-touch' standard can be ascribed to the concept of discretion which Azoulay presents as being 'the principle of all the Commission's interventions in the area of competition policy' and to the idea that the Commission, in this area, enjoys an 'attribution of executive competence that is close to a reserved area'. ${ }^{14}$ Craig also argues that, at the time, a more thorough evaluation would have been too time-consuming, as it would have implied a review of measures which were often taken under time pressure and with an urgent need to tackle a specific problem in the internal market. It is therefore unsurprising, according to Craig, that the Court did not want to engage in complex economic assessments. ${ }^{15}$

However, throughout the years, this apparent position of deference has not prevented the European courts from carrying out a rather strict scrutiny of EU administrative decisions in as far as the establishment of facts is concerned. As such, as Craig has argued, the reference to the threshold of 'manifest error' has not changed, but its scope has evolved throughout time to permit an increasingly intensive review. ${ }^{16}$ This evolving standard of review is analysed in the next section.

\subsection{The Tetra Laval Case and the Path Towards a More Intensive Review}

The move towards a less 'light-touch' approach towards the review of discretionary choices can be first observed in the Technische Universität München case. ${ }^{17}$ The case concerned a preliminary question sent by a German court, which questioned the 'lightness' of the standard of review used by the European Courts. The Court of Justice was clear in holding that

\footnotetext{
${ }^{11}$ See e.g. Case 42/84, Remia and Others $v$ Commission EU:C:1985:327, para. 34. In the context of the Common Agricultural Policy see Case 98/78, A. Racke v Hauptzollamt Mainz, ECLI:EU: C:1979:14.

${ }^{12}$ Craig (2012), p. 411.

${ }^{13}$ Anderson (2014), p. 434.

${ }^{14}$ Azoulay (2001), pp. 429-430.

${ }^{15}$ Craig (2012), p. 415.

${ }^{16}$ Craig (2012), pp. $415-416$.

${ }^{17}$ Case C-269/90, Technische Universität München, ECLI:EU:C:1991:438.
} 
It must be stated first of all that, since an administrative procedure entailing complex technical evaluations is involved, the Commission must have a power of appraisal in order to be able to fulfil its tasks.

However, where the Community institutions have such a power of appraisal, respect for the rights guaranteed by the Community legal order in administrative procedures is of even more fundamental importance.

Those guarantees include, in particular, the duty of the competent institution to examine carefully and impartially all the relevant aspects of the individual case, the right of the person concerned to make his views known and to have an adequately reasoned decision. Only in this way can the Court verify whether the factual and legal elements upon which the exercise of the power of appraisal depends were present.

The Court must therefore examine whether the disputed decision was adopted in accordance with the principles mentioned above. ${ }^{18}$

It is clear that in this case, the Court placed specific emphasis on the respect of procedural principles and the fact that it will not refrain from examining thoroughly the procedural side of EU administrative decision-making. The move towards a more intense 'process review' can be further observed in the subsequent Tetra Laval case ${ }^{19}$ in which the ECJ explained that

whilst ... the Commission has a margin of discretion with regard to economic matters, that does not mean that the Community Courts must refrain from reviewing the Commission's interpretation of information of an economic nature. ${ }^{20}$

On the contrary,

not only must the Community Courts, inter alia, establish whether the evidence relied on is factually accurate, reliable and consistent but also whether the evidence contains all the information which must be taken into account in order to assess a complex situation and whether it is capable of substantiating the conclusions drawn from it. ${ }^{21}$

Despite the formula being repeated on several occasions, ${ }^{22}$ 'academics and practitioners alike are still struggling to grasp fully under what circumstances EU Courts are likely to take fault with the Commission's decision-making and what

\footnotetext{
${ }^{18} \mathrm{Ibid}$., paras 13 to 15 .

${ }^{19} \mathrm{C}-12 / 03$ P, Tetra Laval, ECLI:EU:C:2005:87. For an examination of the Tetra Laval test and the distinction between establishing the facts which are relevant in the decision-making and the appraisal of these facts, and the different review of the European courts see Schimmel and Widdershoven (2009), pp. $61 \mathrm{ff}$.

${ }^{20} \mathrm{C}-12 / 03$ P, Tetra Laval, ECLI:EU:C:2005:87, para. 39.

${ }^{21} \mathrm{C}-12 / 03$ P, Tetra Laval, ECLI:EU:C:2005:87, para. 39. This test has been reiterated in a long line of case law after that. See recently C-389/10 P, KME Germany and others v. Commission, ECLI: EU:C:2011:816, para. 121; T-177/13, TestBioTech eV and Others v. Commission, ECLI:EU: T:2016:736 para. 79. For an examination of Tetra Laval and the subsequent case law Meij (2009), pp. 8-21.

${ }^{22}$ See e.g. T-377/07, Evropaïki Dynamiki - Proigmena Systimata Tilepikoinonion Pliroforikis kai Tilematikis AE v. Commission, ECLI:EU:T:2011:731, para. 22 and the case law cited therein.
} 
errors may strike a fatal blow to the lawfulness of its analysis'. ${ }^{23}$ Notwithstanding the elusiveness of this test, it can nevertheless be established that the European Courts are consistent on the necessity of thorough and careful examination of facts where their establishment is objectively difficult and it requires expert knowledge. ${ }^{24}$ Furthermore, the control exercised by EU courts does not preclude establishing facts independently or reviewing the facts established by the EU authorities with regard to the content (and not only the procedure). ${ }^{25}$ The possibility to carry out an in-depth analysis of the evidence which has served as the basis of the decision under review is also necessary because the European courts have jurisdiction to assess the appropriateness of the interpretation given by the Commission to vague legal notions. ${ }^{26}$

On the basis of this case law, it can be concluded that the European courts have not formally moved away from the 'manifest error' threshold as a standard of review in administrative decision-making, but the case law suggest that, in order to assess whether a manifest error has been committed by the EU institutions, EU courts are required to be able to assess the evidence submitted.

In the words of AG Kokott,

\begin{abstract}
it would be an error to assume that the Commission's margin of discretion precludes the Community Courts in any event from giving their own analysis of the facts and the evidence. On the contrary, it is essential for the Community Courts to undertake such an assessment of their own where they are assessing whether the factual material on which the Commission's decision was based was accurate, reliable, consistent and complete, and whether this factual material was capable of substantiating the conclusions the Commission drew from it. Otherwise, the Community Courts could not sensibly assess whether the Commission had stayed within the limits of the margin of discretion allowed to it or had committed a manifest error of assessment. ${ }^{27}$
\end{abstract}

Commentators are virtually unanimous in concluding that this test provides for a relatively strict review of the Commission's decisions. ${ }^{28}$ Hence, it can be concluded that the current, still Tetra Laval-based, intensity of review exercised by the EU courts, while not requiring a full assessment of the Commission's decisions, does extend to 'a review of factual accuracy, reliability, consistency and completeness of evidence, and allows the court to assess whether it serves as a sufficient basis for

\footnotetext{
${ }^{23}$ Kalintiri (2016), p. 1285 with further references on the debate surrounding the standard of review in economic cases.

${ }^{24}$ T-13/99, Pfizer Animal Health SA v Council of the European Union, ECLI:EU:T:2002:209, para 172.

${ }^{25}$ C-12/03 P, Tetra Laval, ECLI:EU:C:2005:87, para. 39. Of course whether the EU courts do carry out this review in practice and have the instruments to do so, is a different question. See further on this point Kalintiri (2016), pp. 1311-1312.

${ }^{26}$ Baran (2017), p. 307.

${ }^{27} \mathrm{C}-413 / 06, P$ Bertelsmann AG and Sony Corporation of America $v$ Independent Music Publishers and Labels Association (Impala) ECLI:EU:C:2007:790, para. 240.

${ }^{28}$ Wils (2010), p. 31; Lavrijssen and de Visser (2006), p. 131; Lenaerts and Gerard, note that "despite the language of Article [263 TFEU], the 'manifest error of appraisal' standard for reviewing the application by the Commission of Article [101 (3) TFEU] for instance has considerably evolved over time towards a 'full review standard"'. Lenaerts and Gerard (2004), p. 340.
} 
Commission's conclusions'. ${ }^{29}$ Widdershoven considers therefore that 'judicial deference in relation to the substance of the decision, is compensated to some extent by a strict review of the reasons of the decision ${ }^{30}$ Some have gone that far as to argue that the Court of Justice has moved from a mere procedural review of discretionary decisions to a 'quasi-substantive review of the scientific evidence relied upon in the decision-making process ${ }^{31}$

\subsection{Probing the Test of 'Manifest Error' Beyond Competition Law}

\subsubsection{Public Health and the Environment}

A more intense scrutiny compared to the earlier case law can be identified also beyond the field of competition law. A first step towards a more thorough review of the discretionary choices of the EU administration can be observed in Pfizer, which concerned a challenge against a measure withdrawing the authorization for an additive to animal feeding stuffs. ${ }^{32}$ Again, while not formally departing from the test of 'manifest error' the General Court (then called the Court of First Instance) carried out a thorough evaluation to assess whether a manifest error had been committed by the European Commission. This same approach has been repeated also in later case law concerning the regulations of risks to public health or the environment. ${ }^{33}$

Furthermore, in the Schräder case concerning the application for a plant variety right, the General Court (seized in first instance in an action for annulment under Article 263 TFEU) used the Tetra Laval formula and stated that this was the applicable standard of review for cases in which the decision is the result of complex economic or technical assessments. ${ }^{34}$ The General Court moreover added that the same standard could apply in cases where the technical complexity stems from 'appraisals in other scientific domains, such as botany or genetics'. ${ }^{35}$

It can therefore be concluded that, also beyond competition law, whenever the EU administration is faced with technical discretionary choices, the European courts will review whether a 'manifest error' has been committed and will review whether the

\footnotetext{
${ }^{29}$ Baran (2017), p. 311.

${ }^{30}$ Widdershoven (2019), p. 56.

${ }^{31}$ Leonelli (2018), p. 1248 [emphasis added].

${ }^{32}$ Case T-13/99, Pfizer Animal Health SA v Council of the European Union, ECLI:EU:T:2002:209.

${ }^{33}$ See Case T-475/07, Dow Agro Sciences Ltd and Others v European Commission EU:T:2011:445, paras. 150-153; Case T-257/07, France v Commission, EU:T:2011:444, para. 87.

${ }^{34}$ Case T-187/06, Ralf Schräder v Community Plant Variety Office (CPVO), EU:T:2008:511, para. 61.

${ }^{35}$ Ibid, para. 62.
} 
factual basis on which the administration grounded its decision was 'accurate, reliable, consistent and complete', and whether this factual material was 'capable of substantiating the conclusions' the EU authority drew from it.

\title{
2.3.2 Fundamental Rights
}

Also with regard to fundamental rights cases, the case law presents an approach to the review of 'technical discretion' which is similar to the one examined above with regard to competition law. The seminal case in this respect is Kadi II. ${ }^{36}$ The Kadi litigation concerns the freezing of assets of suspected terrorists pursuant to the placing of such people on a list drawn up by the United Nations (UN) Sanctions Committee. In the Kadi II case, the applicant argued that the evidentiary basis underlying the reasons provided by the UN Sanctions Committee for placing his name on the list had to be reviewed by the EU courts. The European Commission, supported by some Member States tried to plead for a limited understanding of the concept of 'manifest error', 'such as an error as to the identity of the person designated' ${ }^{37}$ The General Court disagreed and held that, while

the competent Community institution possesses some latitude in that sphere, that does not mean that the Court is not to review the interpretation made by that institution of the relevant facts. The Community judicature must not only establish whether the evidence relied on is factually accurate, reliable and consistent, but must also ascertain whether that evidence contains all the relevant information to be taken into account in order to assess the situation and whether it is capable of substantiating the conclusions drawn from it. However, when conducting such a review, it is not its task to substitute its own assessment of what is appropriate for that of the competent Community institution. ${ }^{38}$

On appeal, the Commission and the Member States qualified this approach as 'excessively interventionist'. ${ }^{39}$ The Court of Justice however upheld the standard of review used by the General Court and held that

\begin{abstract}
the effectiveness of the judicial review guaranteed by Article 47 of the Charter also requires that, as part of the review of the lawfulness of the grounds which are the basis of the decision to list or to maintain the listing of a given person in Annex I to Regulation No 881/2002 ..., the Courts of the European Union are to ensure that that decision, which affects that person individually ..., is taken on a sufficiently solid factual basis [...]. That entails a verification of the factual allegations in the summary of reasons underpinning that decision [...], with the consequence that judicial review cannot be restricted to an assessment of the cogency in the abstract of the reasons relied on, but must concern whether those reasons, or, at the very least, one of those reasons, deemed sufficient in itself to support that decision, is substantiated. ${ }^{40}$
\end{abstract}

\footnotetext{
${ }^{36}$ Case T-85/09, Yassin Abdullah Kadi v European Commission, ECLI:EU:T:2010:418.

${ }^{37}$ Case T-85/09, Yassin Abdullah Kadi v European Commission, ECLI:EU:T:2010:418, para. 96.

${ }^{38}$ Ibid., para. 142.

${ }^{39} \mathrm{C}-584 / 10$ P, Commission and Others v Kadi, ECLI:EU:C:2013:518, para. 74.

${ }^{40}$ Ibid., para. 119.
} 


\section{Intensity of Review of Discretion stricto sensu in the EU Legal System: Between 'Manifest Error' and the Principle of Proportionality}

The case law above applies to situations in which the EU authorities have to carry out complex factual assessments. The analysis of this case law has revealed that the European courts exercise a rather strict review of the correctness of the factual basis of the discretionary decisions of the EU authorities. This case law, as Mendes has argued, seems to leave considerations of public interest out of the equation, as it enables

\section{the courts to scrutinize those choices that follow logically from factual assessments - as a matter of cognition - not the choices that stem from balancing the public interests that ought to be pursued against those that may be forfeited in the given circumstances - a matter of volition. ${ }^{41}$}

However, often issues of technical discretion and of discretion stricto sensu are intertwined and it is hard to disentangle them. ${ }^{42}$ It is to the review of this latter form of discretion that this contribution now turns. As regards the review of discretion stricto sensu, the case law is split between a review based on 'manifest error' and one based on proportionality review (or possibly a combination of the two).

\subsection{Manifest Error}

As in the review of 'technical discretion', the Court of Justice used the test of 'manifest error' also cases of 'pure discretion'. The landmark case in the field is Westzucker. ${ }^{43}$ In this case the applicant challenged a European Commission Regulation concerning the granting of certain premiums for sugar production.

As Craig explains, the discretion on the part of the Commission in this case is recognizable at two distinct levels of the regulatory scheme: first, because the relevant provision was phrased in terms of merely allowing and not obliging the Commission to grant such premiums; and second, because the criteria according to which the Commission could exercise its discretion were broad and open-ended, including for example the amount of sugar surplus present in the Community and the foreseeable market price for certain alternative products, all of which had to be weighed by the Commission when deciding whether to grant the premium. In this case, the Court displayed a clear restraint in reviewing the choices of the Commission: it stated that the Commission enjoyed in this field a 'significant freedom of evaluation' and therefore the court's review was limited to determine 'whether the

\footnotetext{
${ }^{41}$ Mendes (2016), p. 436.

${ }^{42}$ Ibid., at pp. 419-452.

${ }^{43}$ Case 57/72, Westzucker GmbH v Einfuhr- und Vorratsstelle für Zucker, ECLI:EU:C:1973:30.
} 
evaluation of the competent authority contains a patent error or constitutes a misuse of power'. 44

Furthermore, in this line of case law, as with the review of 'technical discretion' the Court of Justice did not carry out an in-depth analysis of the EU authorities' decisions and 'was normally content with two brief paragraphs before finding that there was no manifest error'. 45

The same approach was repeated in more recent case law. ${ }^{46}$ In a case concerning, as Westzucker, import duties for sugar, the Court of Justice added that

[T]he depth of the Court's review must be limited in particular where [...] the Community institutions have to reconcile divergent interests and thus select options within the context of the policy choices which are their own responsibility. ${ }^{47}$

It is therefore clear that the European courts will not readily re-assess the weighing of interests carried out by the EU administration. As Craig notes, this is bound specifically to be the case in policy areas such as the Common Agricultural Policy, which sets out several objectives which might clash with each other. ${ }^{48}$

\subsection{Proportionality Review}

Discretionary choices of the EU administration are also often reviewed under the heading of proportionality. Proportionality is an important principle of EU administrative law and, although borrowed from the German administrative law tradition, it has acquired an own meaning at EU level. ${ }^{49}$ As in the German legal system, the EU courts consider the relevant interests, and will further enquire as to whether the measure at stake was suitable to achieve the desired end and necessary to it. The

\footnotetext{
${ }^{44}$ Ibid., para. 14 .

${ }^{45}$ Craig (2012), p. 442.

${ }^{46}$ See e.g. Case C-390/95 P, Antillean Rice Mills and Others v Commission, ECLI:EU:C:1999:66, para. 48; Joined Cases C-37 \& 58/06, Viamex Agrar Handels GmbH et al. v Hauptzollamt Hamburg Jonas, ECLI:EU:C:2008:18, para. 34.

${ }^{47}$ C-41/03 P, Rica Foods (Free Zone) NV v Commission, ECLI:EU:C:2005:456, para. 54.

${ }^{48}$ Craig (2012), p. 442. According to Article 39 TFEU, the objectives of the common agricultural policy are
}
(a) to increase agricultural productivity by promoting technical progress and by ensuring the factors of production, in particular labour; rational development of agricultural production and the optimum utilisation of the
(b) thus to ensure a fair standard of living for the agricultural community, in particular by increasing the individual earnings of persons engaged in agriculture;
(c) to stabilise markets;
(d) to assure the availability of supplies;
(e) to ensure that supplies reach consumers at reasonable prices.

${ }^{49}$ See e.g. Tridimas (2007), Chapter 3; Schwarze (2006), Chapter 5. 
latter point requires an examination of whether the end could have been achieved though milder, but equally effective, means.

The German proportionality test requires also a third step, which is often referred to an proportionality stricto sensu, which entails an assessment of whether the burden imposed is proportionate to achieve the desired objective. It is not completely straightforward whether this third limb of the test is also applied by the EU courts when reviewing the discretionary choices of the EU administration. ${ }^{50}$

De Bùrca, who has conducted a thorough study of the use of the principle of proportionality by the EU courts, has stated that, as such, there is not one single application of the principle at EU level. Instead, the courts will exercise a more or less stringent control according to the 'relative expertise, position and overall competence of the Court as against the decision-making authority'. 51 The review of the discretionary choices of the EU authorities is, from this perspective, an example of a rather deferential proportionality review.

For example, in a case concerning certain import arrangements in the banana market, the applicant tried to rely on the principle of proportionality, by arguing that there were possibly less restrictive arrangements. ${ }^{52}$ The General Court did not uphold the argument and departed from the explanation that the Common Agricultural Policy is an area where the EU authorities are granted a wide margin of discretion. In this area,

$[R]$ eview by the Community judicature must be limited in that way in particular if, in establishing a common organisation of the market, the Commission has to reconcile divergent interests and thus select options within the context of the policy choices which are its own responsibility. ${ }^{53}$

As a consequence, according to the court,

the lawfulness of a measure adopted in that sphere can be affected only if the measure is manifestly inappropriate having regard to the objective which the competent institution is seeking to pursue. More specifically, where the Community legislature is obliged, in connection with the adoption of rules, to assess their future effects, which cannot be accurately foreseen, its assessment is open to criticism only if it appears manifestly incorrect in the light of the information available to it at the time of the adoption of the rules in question. $^{54}$

The proportionality review of the court seem, therefore, not to entail a review of the possible choices which the EU authorities could have adopted and an assessment of whether the selected one was the least onerous, but is limited to a mere examination of 'manifest disproportionality'. This limited proportionality review has been

\footnotetext{
${ }^{50}$ Craig (2012), p. 592.

${ }^{51}$ De Búrca (1993), p. 111.

${ }^{52}$ Case T-30/99, Bocchi Food Trade International v Commission, ECLI:EU:T:2001:96.

${ }^{53}$ Ibid., para. 93 .

${ }^{54}$ Ibid., para 92 .
} 
used beyond Common Agricultural Policy cases, to, for example, health and risk management cases. ${ }^{55}$

Craig however suggests that this 'low intensity' proportionality review should not be underestimated, in the sense that, while the Court does not per se review all possible appropriate measures to assess whether the least onerous was chosen, it does review in detail the alleged 'manifest disproportionality of the selected measure. $^{56}$

\section{Conclusions}

From the starting point that the review of the European courts is limited to the legality (and does not extend to the merits) of the decisions taken by the European administrative authorities, the analysis carried out in this contribution has delivered a number of conclusions.

Firstly, whenever the EU administration exercises 'technical discretion' (which often translates into the jargon of 'complex technical assessments'), the review of the European courts on the discretionary choices of the EU administration revolves around the concept of 'manifest error'. While this term has never been explicitly departed from, it has acquired a different meaning throughout time. Indeed, while the earlier case law on the standard of review understood the threshold of 'manifest error' as entailing a very light review, the more recent case law has moved toward a deeper-process-oriented-review, entailing an examination of whether the factual basis of a decision justifies the outcome of the decision itself. As has been argued, the European courts have moved 'from review of the sufficiency of the reasons to review of the adequacy of the reasoning ${ }^{57}$ Importantly, it has been shown that this more intensified review is applicable to situations in which the EU administration was faced with not only economically, but also technically and scientifically complex choices, and also in situations in which EU fundamental rights were at stake.

It should be pointed out that the rationale for a more 'hands-on' approach have been labeled as 'eclectic', ranging from the need to dissipate fears that, in the context of public health decisions, the precautionary principle might be used as a barrier to trade; to the need to alleviate the problematic perception of the Commission acting both as a prosecutor and a judge in competition cases; to the need to protect EU fundamental rights. ${ }^{58}$

\footnotetext{
${ }^{55}$ Case C-77/09 Gowan Comércio Internacional e Serviços Lda v Ministero della Salute, ECLI:EU: C:2010:803, where in para. 82 the Court states that review is limited to cases in which the measure at stake is 'manifestly inappropriate'.

${ }^{56}$ Craig (2012), pp. 595-597.

${ }^{57}$ Baran (2017), p. 314.

${ }^{58}$ Craig (2012), p. 438.
} 
Secondly, this contribution has revealed that, whenever the EU authorities are vested with the discretionary powers to weigh conflicting interests, the control of EU courts, exercised both through the tool of 'manifest error' and through the proportionality review, is relatively limited and will only lead to a finding of unlawfulness if serious flaws in the exercise of the discretionary powers can be detected by the European Courts. With regard to this second type of control of discretion, it can be stated that this limited review is linked to core idea that where the Treaties or the legislator accord a broad discretion to the EU administration, the courts should be wary of substituting their judgment with that of the primary decision-maker.

Finally, it should be pointed that, despite the systematization efforts made in this contribution and elsewhere in literature, the case law of the European courts still displays significant uncertainties with regard to the way in which the courts conceptualize and review the various forms of discretion afforded to the European executive. As argued also elsewhere, ${ }^{59}$ it is therefore to be hoped that, in the future, an attempt will be made by the European courts to more clearly distinguish between 'technical discretion' and discretion stricto sensu and clarify the intensity of review carried out for each form of discretion.

\section{References}

Anderson C (2014) Contrasting models of EU administration in judicial review of risk regulation. Common Mark Law Rev 51(2):424-454

Azoulay L (2001) The Court of Justice and the administrative governance. Eur Law J 7:425-441

Baran M (2017) The scope of EU Courts' jurisdiction and review of administrative decisions - the problem of intensity control of legality. In: Harlow C, Leino P, della Cananea G (eds) Research handbook on EU administrative law. Edward Elgar, pp 292-315

Craig P (2012) EU administrative law, 2nd edn. Oxford University Press

De Búrca G (1993) The principle of proportionality and its application in EC law. Yearb Eur Law 13(1):105-150

Fritzsche A (2010) Discretion, scope of judicial review and institutional balance in European law. Common Mark Law Rev 47(2):361-403

Kalintiri A (2016) What's in a name? The marginal standard of review of "complex economic assessments" in EU competition enforcement. Common Mark Law Rev 53(5):1283-1316

Lavrijssen S, de Visser M (2006) Independent administrative authorities and the standard of judicial review. Utrecht Law Rev 2(1):111-135

Lenaerts K, Gerard D (2004) Decentralisation of EC competition law enforcement: judges in the frontline. World Compet 27(3):313-349

Leonelli GC (2018) European Commission v. Bilbaina and Others: the fine line between procedural and substantive review in cases involving complex technical-scientific evaluations. Common Mark Law Rev 55(4):1217-1249

\footnotetext{
${ }^{59}$ See e.g. Prek and Lefèvre who argue that 'the language of the judgments should reflect the fact that discretion is not a homogeneous concept, and that the intensity of judicial scrutiny may vary accordingly'. Prek and Lefèvre (2019), p. 377.
} 
Meij A (2009) Judicial review in the EC Courts: Tetra Laval and beyond. In: Essens O, Gerbrandy A, Lavrijssen S (eds) National Courts and the standard of review in competition law and economic regulation. Europa Law Publishing, pp 8-21

Mendes J (2016) Discretion, care and public interests in the EU administration: probing the limits of law. Common Mark Law Rev 53(2):419-452

Prek M, Lefèvre S (2019) "Administrative discretion", "power of appraisal" and "margin of appraisal" in judicial review proceedings before the General Court. Common Mark Law Rev 56(2):339-380

Schimmel M, Widdershoven R (2009) Judicial review after Tetra Laval: some observations from a European administrative law point of view. In: Essens O, Gerbrandy A, Lavrijssen S (eds) National Courts and the standard of review in competition law and economic regulation. Europa Law Publishing, pp 51-78

Schwarze J (2006) European administrative law, Revised 1st edn. Thomson/Sweet \& Maxwell

Tridimas T (2007) The general principles of EU law, 2nd edn. Oxford University Press

Widdershoven R (2019) The European Court of Justice and the standard of judicial review. In: de Poorter $\mathrm{J}$ et al (eds) Judicial review of administrative discretion in the administrative state. Springer, pp 39-62

Wils W (2010) The increased level of EU antitrust fines, judicial review and the European Convention on Human Rights. World Compet Law Econ Rev 33(1):5-29

Mariolina Eliantonio is a professor of European and Comparative Administrative Law and Procedure. 